\title{
Keratin 17 modulates hair follicle cycling in a TNF $\alpha$-dependent fashion
}

\author{
Xuemei Tong ${ }^{1}$ and Pierre A. Coulombe ${ }^{1,2,3}$ \\ ${ }^{1}$ Department of Biological Chemistry and ${ }^{2}$ Department of Dermatology, The Johns Hopkins University School of Medicine, \\ Baltimore, Maryland 21205, USA
}

\begin{abstract}
Mammalian hair follicles cycle between stages of rapid growth (anagen) and metabolic quiescence (telogen) throughout life. Transition from anagen to telogen involves an intermediate stage, catagen, consisting of a swift, apoptosis-driven involution of the lower half of the follicle. How catagen is coordinated, and spares the progenitor cells needed for anagen re-entry, is poorly understood. Keratin 17 (K17)-null mice develop alopecia in the first week post-birth, correlating with hair shaft fragility and untimely apoptosis in the hair bulb. Here we show that this abnormal apoptosis reflects premature entry into catagen. Of the proapoptotic challenges tested, K17-null skin keratinocytes in primary culture are selectively more sensitive to TNF $\alpha$. K17 interacts with TNF receptor 1 (TNFR1)-associated death domain protein (TRADD), a death adaptor essential for TNFR1-dependent signal relay, suggesting a functional link between this keratin and TNF $\alpha$ signaling. The activity of NF-kB, a downstream target of TNF $\alpha$, is increased in K17-null skin. We also find that $T N F \alpha$ is required for a timely anagen-catagen transition in mouse pelage follicles, and that its ablation partially rescues the hair cycling defect of K17-null mice. These findings identify K17 and TNF $\alpha$ as two novel and interdependent regulators of hair cycling.
\end{abstract}

[Keywords: Intermediate filament; hair cycle; apoptosis; anagen; catagen]

Supplemental material is available at http://www.genesdev.org.

Received October 21, 2005; revised version accepted March 13, 2006.

The hair-producing tissue, known as the hair follicle, is fascinating from developmental, histological, and physiological standpoints. The various types of hair present in mammalian skin undergo a unique cycle throughout life, with phases of growth (anagen) interspersed with phases of involution (catagen) and rest (telogen) (Hardy 1992). This cycle recapitulates several aspects of hair morphogenesis, a process initiated in the embryo, and requires integration, in time and space, of multiple stimulatory and inhibitory signals (Paus and Cotsarelis 1999; Fuchs et al. 2001; Millar 2002). Premature hair loss due to various factors, including disease, hormonal imbalance, and drug regimens, affects a large fraction of the population (Cotsarelis and Millar 2001; Hadshiew et al. 2004). Most nonmelanoma skin cancers, whose incidence is on the rise, arise clonally from progenitor cells located in hair follicles (Lavker et al. 1993). Thus, there are compelling reasons to understand the fundamentals of hair biology.

A mature hair follicle comprises eight distinct epithelial layers organized in concentric circles around the main axis of the hair. These layers form three major compartments: the innermost hair shaft, the inner root sheath (IRS), and the outer root sheath (ORS) (Fig. 1A).

${ }^{3}$ Corresponding author.

E-MAIL coulombe@jhmi.edu; FAX (410) 614-7567.

Article and publication are at http://www.genesdev.org/cgi/doi/10.1101/ gad.1387406.
During anagen, matrix epithelial cells in the prominent hair bulb proliferate rapidly, giving rise to progenitors for the layers comprising the hair shaft and IRS (Paus and Cotsarelis 1999; Fuchs et al. 2001; Millar 2002). The hair bulb and proximal region above it are destroyed via apoptosis during catagen, producing a short, quiescent telogen hair (Fig. 1A). The mesenchymal dermal papilla is spared from apoptosis, and migrates upward during catagen to maintain physical proximity with the bulge, a local swelling of the ORS that houses a significant fraction of skin epithelial stem cells (Fig. 1A; Paus and Cotsarelis 1999; Fuchs et al. 2001; Millar 2002). Anagen reentry requires the action of a papilla-derived signal (Hardy 1992) that causes bulge epithelial stem cells to proliferate, migrate downward, and differentiate de novo.

In recent years, much progress has been made in identifying the signals and mechanisms contributing to hair follicle morphogenesis during development. These pathways, which include Wnts, sonic hedgehog $(\mathrm{SHH})$, transforming growth factor (TGF)- $\beta$ family members (including bone morphogenetic proteins or BMPs), and others, also operate at the time of anagen re-entry in adult skin (Millar 2002; Jamora et al. 2003; Paus and Foitzik 2004). Numerous studies helped define, with cellular and molecular resolution, how competing cues are integrated by progenitor cells so as to give rise to the intricate architecture of a hair follicle. Considerably less is known, however, about the anagen-catagen transition. While 
Figure 1. Hair cycling defect in $\mathrm{K} 17^{-/-}$ skin. (A) Schematic of anagen, catagen, and telogen phases of the hair cycle. Adapted from Beaudoin et al. (2005) (C) 2005 National Academy of Sciences). $\left(B, B^{\prime}\right)$ Histologic appearance of $\mathrm{K} 17^{+/+}$(wild-type; $B$ ) and $K 17^{-/-}\left(B^{\prime}\right)$ mouse backskin at P14. Shown are hematoxylin/eosin-stained longitudinal sections from backskin of ageand gender-matched mice. Arrows point to hair bulbs. Bars, $50 \mu \mathrm{m}$. $\left(C-C^{\prime \prime}\right)$ TUNEL (green) and Hoechst (blue) stainings of wildtype $(C)$ and $K 17^{-/-}\left(C^{\prime}, C^{\prime \prime}\right)$ mouse skin at P14. Arrows point to TUNEL-positive nuclei. Bars, $50 \mu \mathrm{m}$. $\left(D-D^{\prime}\right)$ In situ hybridization analysis of FGF5 mRNA in $\mathrm{K}^{17^{+/+}}$and $K 17^{-/-}$hair follicles at P7. Four percent paraformaldehyde-fixed frozen sections were hybridized with antisense $\left(D, D^{\prime}\right)$ or sense $\left(D^{\prime \prime}\right)$ probes. Asterisks in $D-D^{\prime \prime}$ denote melanin pigment. Arrows point to hybridization signals. Bars, $50 \mu \mathrm{m}$. (E) Northern blot analysis of RNA $(20 \mu \mathrm{g})$ prepared from backskin of $\mathrm{K} 7^{+/+}$and $\mathrm{K} 17^{-/-}$mice at P5, P7, P10, P16, and P20, and probed for FGF5 and $\beta$-tubulin mRNAs. Signal was quantitated in a PhosphorImager and normalized to $\beta$-tubulin. Average values of two independent experiments are reported below each lane. $\left(F-F^{\prime \prime}\right)$ In situ hybridization analysis of PTHRP mRNA in $K 17^{+/+}$and $K 17^{-/-}$hair follicles at P12. Four percent paraformaldehyde-fixed frozen sections were hybridized with antisense $\left(F, F^{\prime}\right)$ or sense $\left(F^{\prime \prime}\right)$ probes. Asterisks in $F-F^{\prime \prime}$ denote melanin pigment. Arrows point to hybridization signals. Bars, $50 \mu \mathrm{m}$. $\left(G-G^{\prime \prime}\right)$ Dual immunostaining for $\mathrm{BrdU}$ (green) and keratin $(H)$ and $K 17^{-/-}\left(H^{\prime}\right)$ mouse backskin at P22. Shown are hematoxylin/eosin-stained longitudinal sections from backskin of age- and gender-matched mice. Arrows point to dermal papillae $(H)$ or hair bulbs $\left(H^{\prime}\right)$. Bars, $50 \mu \mathrm{m}$. (Bulb) Hair bulb; (DP) dermal papilla; (epi) epidermis; (IRS) inner root sheath; (mat) matrix; (ORS) outer root sheath; (SG) sebaceous gland.

several key signals including fibroblast growth factor (FGF)-5 (Hebert et al. 1994), parathyroid hormone-related peptide (PTHRP) (Cho et al. 2003), TGF- $\beta 1$ (Foitzik et al. 2000), and interferon (IFN)- $\gamma$ (Hirota et al. 2002, 2003) have been implicated, much remains to be learned about the mechanisms regulating this carefully controlled tissue regression.

Unlike their wild-type littermates, mice null for the type I keratin 17 (K17) gene fail to develop a full pelage hair coat during the first week after birth (McGowan et al. 2002). This finding was unexpected, as more than half of the $\sim 50$ known keratin genes are expressed in hair follicle tissue alone, often in overlapping patterns (Langbein et al. 2003; Tong and Coulombe 2004). Keratins are intermediate filament-forming proteins, and represent major cellular constituents in complex epithelia. Two types of keratin sequences, I and II, can be distinguished, reflecting a biochemical requirement for both during the multistep assembly reaction that produces a 10-12-nmwide keratin filament (Fuchs 1995). Type I and II keratin genes are cotranscribed in a pairwise, tissue-type, and differentiation-related fashion, providing useful markers to study epithelia in health and disease (Fuchs 1995; Omary et al. 2004). In K17-null mice, pelage hair loss correlates in part with hair shaft fragility, consistent with the major function of structural support shared by all keratins. In addition, abnormal apoptosis occurs in hair bulb tissue, possibly reflecting the novel "prosurvival" role evidenced for select keratins (Oshima 2002; Coulombe and Wong 2004). Of note, the pelage skin phenotype of K17-null mice is reversible and strain-dependent, correlating with a compensatory up-regulation in K16 (McGowan et al. 2002). Here, we show that the untimely apoptosis in hair follicles of K17-null mice, beginning at postnatal day 5 (P5), corresponds to a premature anagen-catagen transition. K17-null keratinocytes in primary culture are selectively more sensitive to $\mathrm{TNF} \alpha$-induced apoptosis. We further show that TNF $\alpha$ is required for a timely anagen-catagen transition in pelage hair follicles, that TNF $\alpha$ signaling is enhanced in $\mathrm{K} 17$ - 
null skin, and finally, that loss of TNFo partially rescues the hair cycling defect of K17-null mice. The interaction between $\mathrm{K} 17$ and the death adaptor protein TRADD (TNFR1 [TNF receptor 1]-associated death domain protein) provides further evidence for a functional link between this keratin and TNF $\alpha$ signaling. These findings identify K17, a structural protein, and $\mathrm{TNF} \alpha$, a proinflammatory cytokine, as two novel and interdependent regulators of hair cycling.

\section{Results}

Loss of K17 causes premature catagen entry in pelage hair follicles

Four lines of evidence suggest that hair follicles prematurely enter catagen in K17-null mouse skin. First, routine histology conducted at P14 shows that wild-type hair follicles are in anagen, as evidenced by their maximal length and bell-shaped bulb region (Fig. 1B). In contrast, K17-null hair follicles are in catagen, as shown by their shortening and the narrowing and destruction of bulb tissue (Fig. 1B'). Second, TUNEL assay shows the presence of many apoptotic cells in the lowermost portion of involuting hair follicles in K17-null, but not wildtype, skin (Fig. 1C-C"). Third, two key markers of the anagen-catagen transition, FGF5 and PTHRP, are misregulated in K17-null backskin. The FGF5 mRNA is normally low during early and mid-anagen, begins to rise at approximately P10 in the hair matrix and ORS, and peaks in late anagen (Hebert et al. 1994). By in situ hybridization, we find that FGF5 is up-regulated in a subset of hair follicles at P7 in K17-null skin, while no signal is detected in wild type (Fig. 1D-D"). By Northern analysis, FGF5 is slightly up-regulated at P5, and more so at P7 and P10 in K17-null skin, compared with wild type (Fig. 1E). While FGF5 reaches peak levels at P16 in the control, it has already decreased in K17-null skin (Fig. 1E). The PTHRP mRNA is normally expressed during anagen and is down-regulated at catagen entry (Cho et al. 2003). In situ hybridization shows that PTHRP is down-regulated at P12 in K17-null hair follicles, while it is still expressed in the ORS of wild-type follicles (Fig. 1F-F"). Finally, exit from anagen requires a decrease in cell proliferation in the hair matrix. At P5, we find a significant reduction $(\sim 30 \%)$ in the frequency of BrdU-positive cells in this region of K17-null hair follicles, relative to wild type (Fig. 1G-G"). Altogether, these findings establish that hair follicles prematurely commit to the catagen phase of the hair cycle, starting at P5/P7, in K17-null backskin.

Histology was conducted on backskin tissue at later time points to determine whether additional aspects of hair cycling are affected in K17-null mice. At P20, wildtype and K17-null hair follicles are in telogen and early anagen, respectively (data not shown). At P22, wild-type follicles are still in telogen (Muller-Rover et al. 2001), whereas K17-null follicles have progressed further in anagen, as evidenced by the presence of a well-defined bulb (Fig. 1H-H'). Coinciding with the ectopic induction of K16 in hair matrix epithelial cells and normalization of the pelage phenotype (McGowan et al. 2002), the length of the second anagen is not significantly altered in K17-null hair follicles (data not shown). These data suggest that, in the absence of effective compensatory mechanisms, loss of K17 selectively affects the anagencatagen transition of the hair cycle.

The finding that nullifying a single keratin gene perturbs hair cycling was unexpected. To assess whether this defect specifically results from loss of K17, we reintroduced K17 protein in K17-null mice. All aspects of the skin phenotype, including hair fragility, hair cycling defect, and premature apoptosis in hair follicles, are normalized in the K17 replacement mice (Supplementary Fig. 1). This confirms that the hair alterations associated with the K17-null mutation are specifically due to loss of K17 protein.

\section{K17-null keratinocytes are selectively more sensitive to TNF $\alpha$-mediated apoptosis}

To explore the molecular basis of untimely apoptosis in K17-null hair follicles, we examined the response of keratinocytes in primary culture to a Fas-, TNF $\alpha-$, and TRAIL-induced apoptotic challenge in the presence of cycloheximide (CHX) (Caulin et al. 2000). Each of these pathways is operational in skin keratinocytes (Wehrli et al. 2000). Additionally, defects in K8/K18 filaments increase the susceptibility of trophectoderm and adult liver hepatocytes to specific proapoptotic signals including $\mathrm{TNF} \alpha$ and $\mathrm{FasL}$, a finding that is reproduced in epithelial cell lines (Caulin et al. 2000; Gilbert et al. 2001; Jaquemar et al. 2003; Ku et al. 2003). In the context of primary culture, newborn mouse skin keratinocytes express K17 and K14 uniformly, and K16 in a patchy fashion (Wawersik and Coulombe 2000). Expression of K17 and K16 in this setting likely reflects the elaboration of a wound repair program in serum-exposed keratinocytes (Weiss et al. 1984).

Treatment with dimethyl sulfoxide (DMSO) (CTL) produced very little apoptosis over $24 \mathrm{~h}$ in wild-type and K17-null keratinocytes (Fig. 2A,B,C, $\mathrm{C}^{\prime}$ ). Of all the treatment combinations tested, TNF $\alpha$ and TRAIL gave rise to a greater degree of apoptosis. K17-null cells $(24.1 \pm 3.5 \%)$ showed more apoptosis than wild type $(15.8 \pm 0.9 \%)$ in response to TNF $\alpha$ (Fig. 2A,B). This difference was obvious in TUNEL-stained preparations (Fig. 2C-D'). No difference was observed for any other treatment (Fig. 2A,B), and following UVB exposure (data not shown). This differential TNF $\alpha$ responsiveness is likely underestimated since (1) these cultures contain mostly epidermis-derived, instead of hair follicle-derived, keratinocytes (Marcelo et al. 1978); and (2) K14 and K16 are expressed as well, raising the prospect of phenotypic rescue in the setting of primary culture (see below).

To assess whether K17 acts cell-autonomously in this setting, K17-null keratinocytes were transiently transfected with CMV promoter-K17 cDNA, and subjected 36 $\mathrm{h}$ later to $\mathrm{TNF} \alpha / \mathrm{CHX}$ treatment. A greater fraction of K17-null keratinocytes $(31.5 \pm 2.0 \%)$ showed apoptosis 
Figure 2. K17-null keratinocytes show increased apoptosis following TNF $\alpha$ treatment. $(A, B)$ Response of wild-type and $K 17^{-/-}$keratinocytes in primary culture to various proapoptotic treatment combinations. (CTL) DMSO-treated controls; (CHX) cycloheximide. Other treatments are self-explanatory. A shows the percentage of apoptotic cells based on TUNEL and Hoechst staining, while $B$ shows a caspase activity assay (RFU, relative fluorescence units). Both $A$ and $B$ show that $K 17^{-/-}$ keratinocytes are selectively more sensitive to $\mathrm{TNF} \alpha+\mathrm{CHX}$ treatment than wild type. $\left({ }^{\star}\right) p<0.01$. (C$\left.D^{\prime}\right)$ Representative micrographs from wild-type and $\mathrm{K} 17^{-/-}$cultures treated with DMSO vehicle (CTL) or $\mathrm{TNF} \alpha+\mathrm{CHX}$. Dual TUNEL (green) and Hoechst (blue) stainings are shown. Arrows denote TUNEL-positive nuclei. Bars, $20 \mu \mathrm{m}$. (E) Comparing the sensitivity of $\mathrm{K}_{17^{-/-}}$keratinocytes (K17-null N-TF) to TNF $\alpha+\mathrm{CHX}$ treatment after transfection with wild-type $K 17 \mathrm{cDNA}$ (K17-null TF). Percentage of apoptotic cells is based on TUNEL and Hoechst stainings (see $A$ ). Cells re-expressing $\mathrm{K} 17$ are significantly less sensitive to treatment than K17 ${ }^{-/-}$cells. $P<0.001$.
A
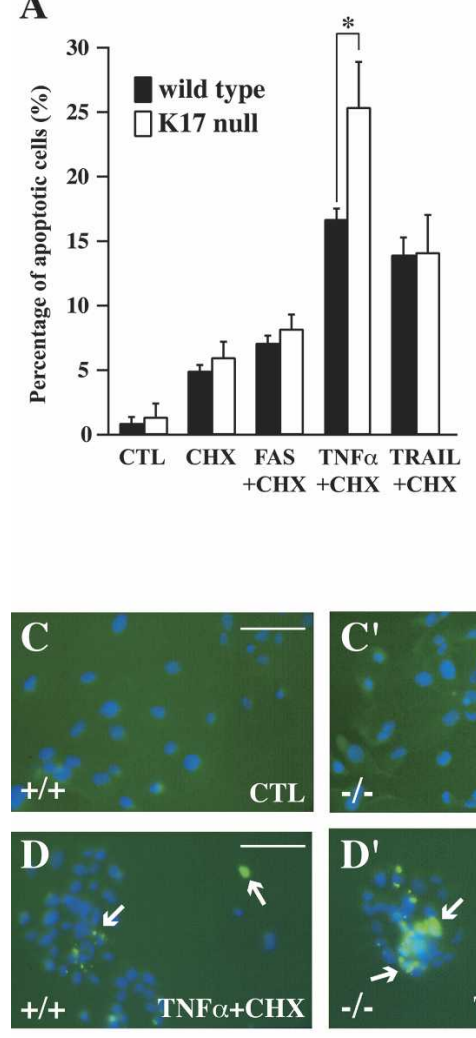

B

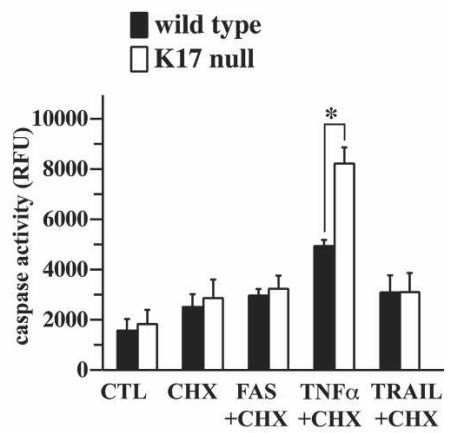

E

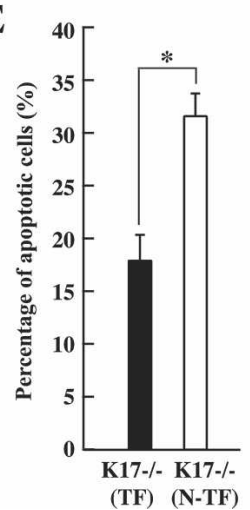

under these conditions (Fig. 2E), likely owing to the stress of lipofectamine-mediated transfection. Neighboring K17-re-expressing keratinocytes showed significantly less apoptosis $(18.2 \pm 2.3 \% ; p<0.001)$, as expected (Fig. 2E). Together, these findings show that loss of K17 cell-autonomously increases the susceptibility of cultured skin keratinocytes to $\mathrm{TNF} \alpha$-mediated apoptosis, suggesting that such may be the case as well in vivo.

K17 interacts with TRADD, a death adaptor, in mouse skin keratinocytes

That K17, a cytoskeletal protein, influences the responsiveness of keratinocytes to $\mathrm{TNF} \alpha$ is a priori surprising. The previously documented interaction between K18 and TRADD (Inada et al. 2001), a death adaptor protein essential for signal relay downstream from TNF receptor 1 (TNFR1) (Micheau and Tschopp 2003), provides a possible mechanism. Inada et al. (2001) found that the K18TRADD interaction affords a protection against $\mathrm{TNF} \alpha-$ induced apoptosis, possibly via the sequestration of TRADD away from TNFR1. TRADD also binds K14 in a human keratinocyte cell line (Yoneda et al. 2004). Mapping studies showed that TRADD binds the 1A subdomain in K18 (Inada et al. 2001) and K14 (Yoneda et al. 2004), a region that is highly conserved in other type I keratins. The physiological significance of these interactions in vivo is unknown.

Coimmunoprecipitation assays using two distinct antibodies revealed that, as expected, K17, K16, and K14 are present in endogenous TRADD immunoprecipitates obtained from primary cultures of mouse skin keratinocytes (Fig. 3A, $\left.\mathrm{A}^{\prime}\right)$. In mouse keratinocytes transfected with GFP fusion constructs, both full-length TRADD (residues 1-312) (Fig. 3B-B") and its C-terminal moiety (residues 105-312) (Fig. 3C-C") partially colocalize with $\mathrm{K} 17$ in the cytoplasm. Similar results were obtained in preparations double-stained for K14 and TRADD (data not shown). In contrast, the $\mathrm{N}$ terminus of TRADD (residues 1-105) shows a diffuse distribution in the cytoplasm and nucleus (data not shown). Partial colocalization between TRADD, a signaling adaptor present at low levels, and the abundant K17 does not preclude a physiologically relevant interaction. The finding that TRADD potentially interacts with K14 and K16 in vivo is significant, as K16 has been implicated in the reversibility and strain-dependence of the hair phenotype in K17-null mice (McGowan et al. 2002). Additional studies are required to ascertain whether altered regulation of TRADD is, indeed, involved in the increased susceptibility of K17-null keratinocytes to TNF $\alpha$-induced apoptosis.

TNF $\alpha$ signaling contributes to hair cycle regulation in Vivo

There is as yet no definitive evidence implicating the $\mathrm{TNF} \alpha / \mathrm{TNFR} 1$ signaling pathway in mature hair follicles of postnatal mouse skin. Several conditions need to be met to support the possibility that TNF $\alpha / T N F R 1$ play a 
A

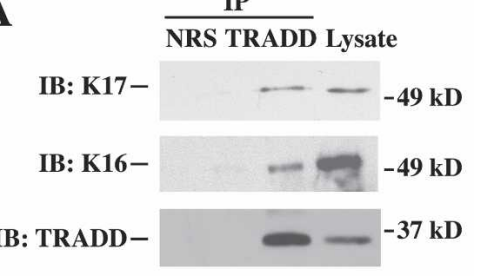

$\mathbf{A}^{\prime}$

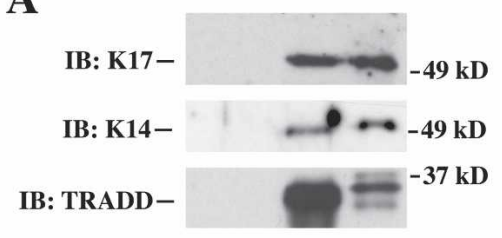

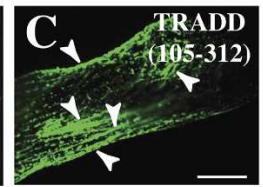
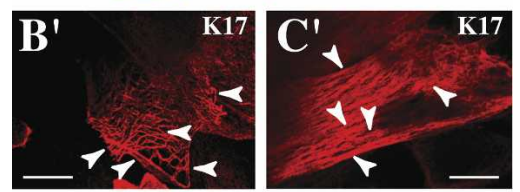

$\mathbf{B}^{\prime \prime}$
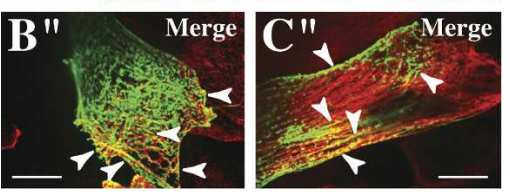

Figure 3. Association between K17 and TRADD in skin keratinocytes. $\left(A, A^{\prime}\right)$ Immunoprecipitates from lysates prepared from wild-type mouse skin keratinocytes in primary culture, using normal rabbit serum (NRS) and two distinct anti-TRADD polyclonal antibodies, obtained from Santa Cruz Biotechnology (A) and Dr. M. Inagaki (Aichi Cancer Research Institute, Nagoya, Japan) (Inada et al. 2001) $\left(A^{\prime}\right)$. Precipitates were subjected to Western blotting with anti-K17, anti-K16, anti-K14, or anti-TRADD polyclonal antibody, as indicated at left. The migration of $37-$ and $49-\mathrm{kDa}$ markers is shown at right. $\left(B-C^{\prime \prime}\right)$ Indirect immunofluorescence of wild-type keratinocytes in primary culture transiently transfected with EGFP-TRADD fusion contructs. ( $\left.B-B^{\prime \prime}\right)$ Full-length TRADD (312 residues long). ( $\left.C-C^{\prime \prime}\right)$ TRADD's C terminus (residues 105-312). The signal detected (GFP, K17, or merge) is identified in the upper right corner. Arrowheads point to instances of colocalization. Bars, $30 \mu \mathrm{m}$.

role in hair cycling, and specifically, in the defect exhibited by K17-null mice: (1) Key pathway components such as TNFR1 and TRADD should be coexpressed with K17 in follicles (consistent with a cell-autonomous mechanism); (2) inactivation of this pathway should delay the anagen-catagen transition in otherwise normal skin; (3) TNF $\alpha /$ TNFR1-dependent signaling should be enhanced in K17-null skin; and (4) abrogation of TNF $\alpha$ should ameliorate if not rescue the hair cycling defect in K17-null skin.

We first sought to determine whether TNFR1 and TRADD are expressed in K17-expressing keratinocytes within hair follicles (Fig. 4A, $\mathrm{A}^{\prime}$ ). This is a prerequisite for

a cell-autonomous, K17-dependent modulation of TNFR1/TRADD signaling in hair tissue. Using in situ hybridization, we found that both TNFR1 (Fig. 4B, $\mathrm{B}^{\prime}$ ) and TRADD (Fig. 4C, $\mathrm{C}^{\prime}$ ) mRNAs occur in the hair matrix and ORS compartments of anagen-stage wild-type follicles, in a pattern that overlaps significantly with that of K17 (Fig. 4A, A').

Next, we indirectly measured the activity of $\mathrm{TNF} \alpha /$ TNFR1-dependent signaling during normal hair cycling through monitoring $\mathrm{I} \kappa \mathrm{B} \alpha$ mRNA levels between P 5 and P28 in wild-type mouse skin. The $I \kappa B \alpha$ gene is a direct transcriptional target of NF- $\mathrm{B}$, which is activated following the engagement of TNFR1 (Hoffmann et al. 2002; Micheau and Tschopp 2003) and related receptors (Moynagh 2005). The $I \kappa B \alpha$ mRNA occurs at low levels between P5 and P14, when follicles are in anagen (Fig. $4 \mathrm{D}, \mathrm{D}^{\prime}$ ). Near the point of catagen entry (approximately P16), its level rises and reaches a plateau that is maintained between P18 and P22. At P25, near the onset of the next anagen phase, $I \kappa B \alpha$ mRNA levels have returned to precatagen levels (Fig. 4D,D'). In light of our finding of delayed catagen entry in mice lacking TNF $\alpha$ (see below), the hair cycle dependency of $I \kappa B \alpha$ regulation, at the mRNA level, likely reflects parallel fluctuations in TNFR1 signaling in vivo. By comparison, K17 protein is regulated in a reciprocal fashion during hair cycling: Its level increases progressively during anagen in wild-type backskin, reaching peak levels between P12 and P16, but is markedly reduced during catagen and telogen (between P18 and P25) (Fig. 4E). K17 levels reincrease at P28, coinciding with the next anagen (Fig. 4E). These findings significantly extend previous studies focusing on K17 mRNA (Panteleyev et al. 1997; see also Lin et al. 2004). Whereas its level also increases during anagen, $\mathrm{K} 16$ is distinct from $\mathrm{K} 17$ in that it peaks during the P18P25 interval (Fig. 4E); that is, during catagen/telogen (Bernot et al. 2002). Other keratin proteins, including K5, do not show such hair cycle-related fluctuations /data not shown). These observations indicate that $\mathrm{K} 17$ is poised to attenuate $\mathrm{TNF} \alpha / \mathrm{TNFR} 1$-dependent signaling during anagen in pelage hair follicles.

Next, we analyzed C57Bl/6 mice null for the TNF $\alpha$ gene to assess whether the loss of this cytokine impacts hair follicle cycling. $T N F \alpha$-null mice are viable and do not exhibit an obvious phenotype unless immunologically challenged (Pasparakis et al. 1996). Histologically, we find that $T N F \alpha$-null hair follicles show a delayed entry into catagen. At P16, hair follicles are still in anagen in TNFo-null backskin, whereas they have already initiated catagen, as expected, in control $\mathrm{TNF}^{+/-}$littermates (Fig. 4F, $\mathrm{F}^{\prime}$ ). Accordingly, no apoptosis can be detected in TNF $\alpha$-null hair follicles at P16 (Fig. 4G', G'), while controls showed significant TUNEL staining and narrowing in the bulb region (Fig. 4G). The morphological findings are substantiated by Northern analyses. Thus, higher levels of two markers of late anagen, FGF5 and PTHRP, occur at P16 in TNF $\alpha$-null skin, relative to control (Fig. $4 \mathrm{H}, \mathrm{I})$. Conversely, the mRNAs for two direct NF- $\mathrm{BB}$ tar-

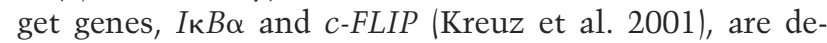
creased at P14, and especially at P16 (by twofold), in 
TNF $\alpha$-null skin (Fig. 4H,I), providing further evidence that NF- $\mathrm{B}$ activity is a reliable indicator of $\mathrm{TNF} \alpha /$ TNFR1 activity in mouse postnatal skin. These findings establish that loss of TNF $\alpha$ causes a modest but consistent delay in catagen entry in mouse backskin (by $\sim 1.5 \mathrm{~d}$, based on histology), thus revealing a previously unknown role for this cytokine in hair cycling. Since the ablation of FGF5, so far defined as the most significant signal in this context, delays catagen entry by only $\sim 2-3$ $\mathrm{d}$ (Hebert et al. 1994), the finding that loss of TNF $\alpha$ does not abrogate this key step altogether could be anticipated.

\section{Alteration in NF- $\mathrm{B}$ activity in K17-null skin}

Although subject to a complex regulation in response to engagement of receptors other than TNFR1 (Moynagh 2005), the findings reported above suggest that NF-кB
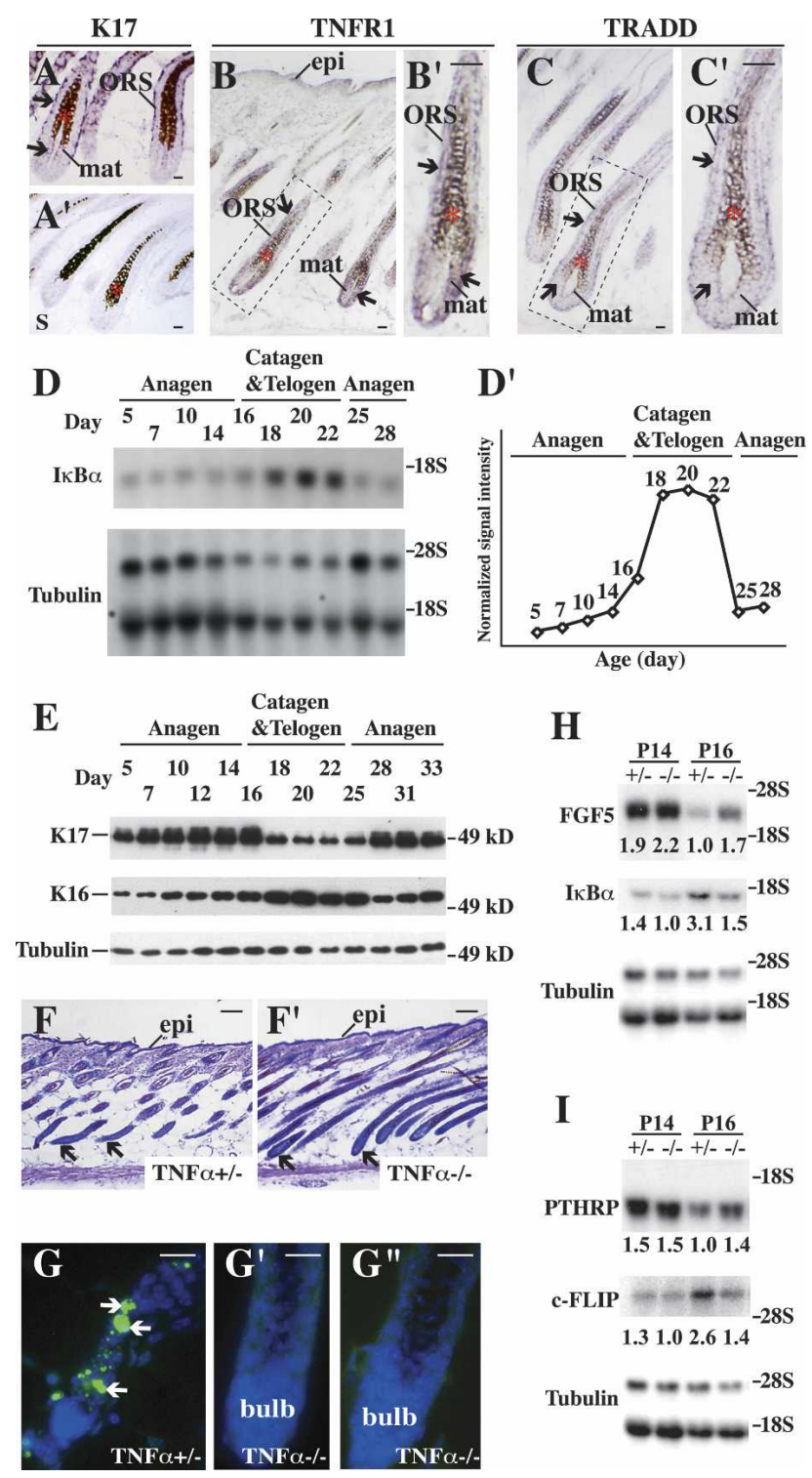

activity can be used as an indicator of TNF $\alpha$-dependent signaling in mouse postnatal skin. To assess NF-кB activity at the time of phenotype onset in K17-null skin, we examined the expression of several of its target genes. By Northern analysis, the $I \kappa B \alpha$ mRNA level is increased by $40 \%$ at $\mathrm{P} 5$ and $80 \%$ at $\mathrm{P} 7$ in $\mathrm{K} 17$-null tissue relative to controls (Fig. 5A). The c-FLIP mRNA level is increased by $20 \%$ and $70 \%$ at P5 and P7, respectively, in K17-null tissue (Fig. 5B). Greater increases, that is, $120 \%$ at P5 and $135 \%$ at P7, occur for yet another well-known NF-кB target gene, ICAM-1 (Fig. 5C; Kondo and Sauder 1997; Min et al. 2005). In situ hybridization studies, conducted at $\mathrm{P} 7$, showed that $I \kappa B \alpha\left(\right.$ Fig. $\left.5 \mathrm{D}^{\prime}\right), c$-FLIP (Fig. $\left.5 \mathrm{E}^{\prime}\right)$, and ICAM-1 mRNAs (Fig. 5F') are markedly elevated in the matrix and ORS in a subset of hair follicles in K17-null skin, thereby enhancing the significance of the Northern findings. Only weak hybridization for these mRNAs was detected in control skin tissue (Fig. 5D-F). Next, we performed subcellular fractionation of backskin tissue coupled with Western analysis to assess translocation of p65 (relA) to its site of action, the nucleus (Scott et al. 1993). Coinciding with the increased expression of NF$\kappa \mathrm{B}$ target genes starting at P5, there is a significant increase in nuclear relA (p65) along with a decrease in cytoplasmic levels of IкB $\alpha$ protein in K17-null skin relative to the control (Fig. 5G). RelA (p65) could not be localized in mouse skin owing to a lack of antibodies suitable for immunostaining of tissue sections (our unpublished data).

Figure 4. Characterization of TNF $\alpha$ signaling in wild-type mouse skin. $\left(A-C^{\prime}\right)$ In situ hybridization for $K 17\left(A, A^{\prime}\right)$, TNFR1 $\left(B, B^{\prime}\right)$, and TRADD $\left(C, C^{\prime}\right)$ mRNAs in hair follicles of P5-P7 wild-type mice. Four percent paraformaldehyde-fixed frozen sections were hybridized with antisense $(A, B, C)$ or sense probes as controls $\left(A^{\prime}\right.$; data not shown) for the designated transcripts. The boxed areas in $B$ and $C$ are shown at higher magnification in $B^{\prime}$ and $C^{\prime}$, respectively. Asterisks denote melanin pigment. Arrows point to hybridization signals. (Bulb) Hair bulb; (epi) epidermis; (mat) matrix; (ORS) outer root sheath. Bars, $20 \mu \mathrm{m}$. $\left(D, D^{\prime}\right)$ Northern blot analysis of total RNA $(20 \mu \mathrm{g})$ prepared from backskin of wild-type mice at different ages, and probed for $I \kappa B \alpha$ and $\beta$-tubulin (loading control) mRNAs. $\left(D^{\prime}\right)$ Normalized

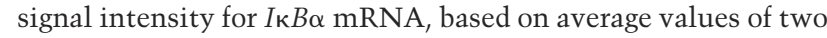
independent experiments. The P5 value, used as a reference, has been normalized to 1 . Peak levels of $I \kappa B \alpha$ mRNA $(3.86 \pm 0.02)$ occur at P20. (E) Western blot analysis of K17 and K16 levels in total protein extracts $(2.5 \mu \mathrm{g})$ prepared from backskin of wildtype mice at different ages. The tubulin blot serves as a loading control. $\left(F, F^{\prime}\right)$ Histology of $T N F \alpha^{+-}(F)$ and $T N F \alpha^{-1-}\left(F^{\prime}\right)$ skin at P16. Shown are hematoxylin/eosin-stained staining longitudinal sections from backskin of age- and gender-matched mice. Arrows point to hair bulbs. Bars, $50 \mu \mathrm{m}$. $\left(G-G^{\prime \prime}\right)$ TUNEL (green) and Hoechst (blue) stainings of $T N F \alpha^{+-}(G)$ and $T N F \alpha^{-/-}\left(G^{\prime}, G^{\prime \prime}\right)$ skin tissue at P16. Bars, $50 \mu \mathrm{m}$. $(H, I)$ Northern blot analysis of total RNA $(20 \mu \mathrm{g})$ prepared from backskin of $\mathrm{TNF}^{+-}$or $T N F \alpha^{-/-}$at P14 and P16, and probed for FGF5 and $I \kappa B \alpha$ (in $H$ ), PTHRP and $c$-FLIP (in I) mRNAs. Signal was quantitated by PhosphorImager and normalized to $\beta$-tubulin. Average values from two independent experiments are reported below each lane. 

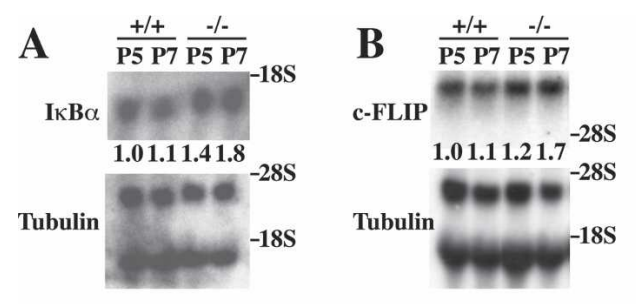

$\mathbf{I} \kappa \mathbf{B} \alpha$
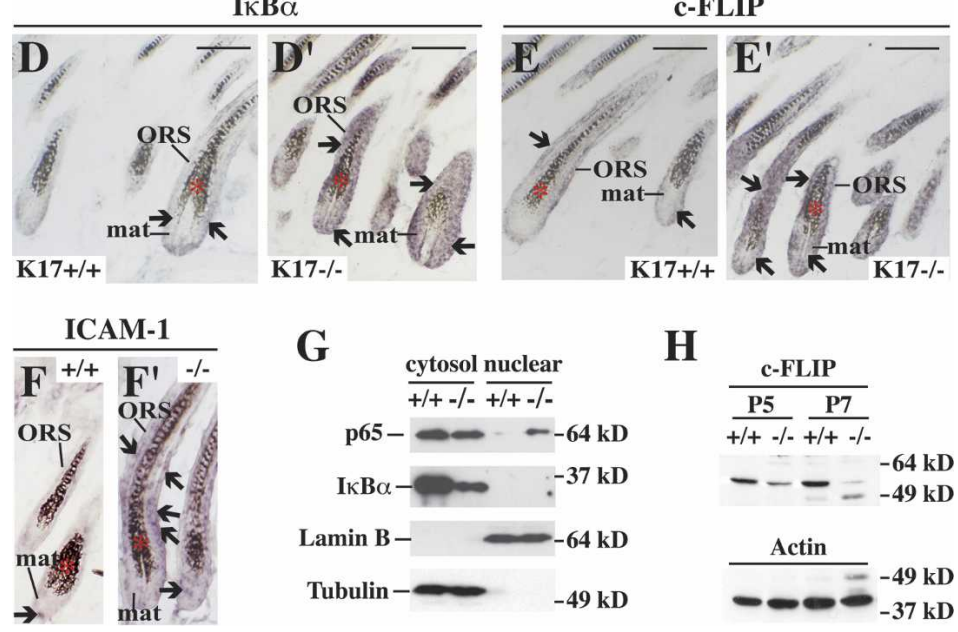

H

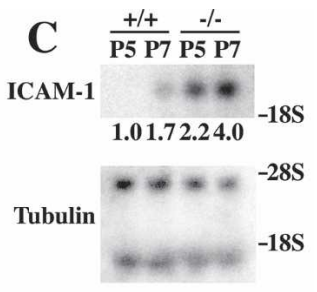

c-FLIP

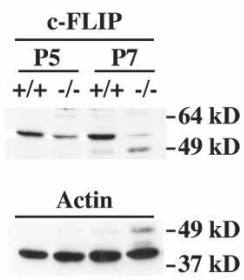

Figure 5. Increased NF- $\mathrm{kB}$ activity in K17-null skin. $(A-C)$ Northern blot analysis of total RNA $(20 \mu \mathrm{g})$ prepared from backskin of $\mathrm{K} 7^{+/+}$and $\mathrm{K}_{17^{-/-}}$mice at P5 and

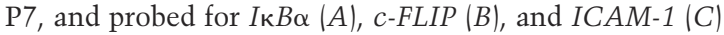
mRNAs. Signal was quantitated by PhosphorImager and normalized to $\beta$-tubulin. The average values of two or three independent experiments are reported below each lane. $\left(D-F^{\prime}\right)$ In situ hybridization analysis for $I \kappa B \alpha$ $\left(D, D^{\prime}\right), c-F L I P\left(E, E^{\prime}\right)$, and ICAM-1 $\left(F, F^{\prime}\right)$ mRNAs in backskin tissue from $K 17^{+/+}$and $K 17^{-/-}$mice at P7. Sections were hybridized with antisense $\left(D-F^{\prime}\right)$ or sense probes (as control; data not shown) for the designated transcripts. Asterisks denote melanin pigment. Arrows point to hybridization signals. Bars, $50 \mu \mathrm{m}$. $(G)$ Western blot analysis of cytosol and nuclear fraction prepared from backskin of $K 17^{+/+}$and $K 17^{-/-}$mice at P5 using anti-p65, anti-IкB $\alpha$, anti-lamin $\mathrm{B}$, or anti-tubulin antibody. Lamin $\mathrm{B}$ and tubulin serve as controls for both loading and fractionation. Note that there is more relA (p65) in the nuclear fraction and less IкB $\alpha$ protein in the cytosol fraction of $\mathrm{K} 7^{-/-}$than $\mathrm{K} 17^{+/+}$control. $(\mathrm{H})$ Western blot analysis of total proteins $(30 \mu \mathrm{g})$ extracted from backskin of $\mathrm{K} 7^{+/+}$and $\mathrm{K} \mathrm{7}^{-/-}$mice at P5 and P7 using an anti-cFLIP antibody. Actin serves as a loading control.
As part of a negative feedback loop, c-FLIP protein counteracts the proapoptotic role of the TRADD-, RIP1-, and TRAF2-containing complex following TNFR1 activation (Micheau and Tschopp 2003; Wachter et al. 2004). In contrast to its mRNA, intact c-FLIP protein is markedly decreased in K17-null, compared with wild type, at P5 and P7 (Fig. 5H; Gilbert et al. 2004). Other than apoptosis and NF- $\mathrm{kB}$ activation, TNF $\alpha$ also cause phosphorylation and activation of JNK (Zhang et al. 2004). We find, however, that the levels of activated JNK do not differ between genotypes at P5 or P7 in total skin protein extracts (data not shown).

Loss of TNF $\alpha$ can partially rescue the apoptotic phenotype of K17-null hair follicles

The model suggested by our findings predicts that the hair cycling defect in K17-null mice should be normalized, to some degree, by loss of $T N F \alpha$. To put this notion to a stringent test, we generated double-null mice $\left(\mathrm{K}^{17^{-/-}} \mathrm{TNF}^{-/-}\right)$in the C57Bl/6 strain background. Several parameters were assessed, between $\mathrm{P} 7$ and $\mathrm{P} 14$, in

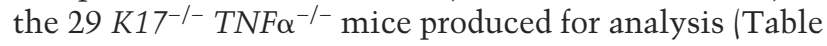

1). A significant fraction of $\mathrm{K} 17^{-/-} \mathrm{TNF} \alpha^{-/-}$mice $(31 \%)$ showed no apoptosis (Fig. 6C-C') in their pelage follicles, correlating with well-developed, bell-shaped hair bulbs characteristic of anagen-stage follicles (Fig. 6B-B'). Simi-

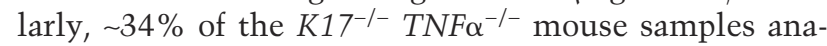
lyzed by in situ hybridization showed low levels of FGF5 mRNA, as is the case in wild-type mice (Fig. 6D-D'; Table 1). In both instances, the difference between $\mathrm{K}_{17^{-/-}} \mathrm{TNF \alpha}^{-/-}$and $\mathrm{K} 17^{-/-} \mathrm{TNF} \alpha^{+/+}$mice reached a high degree of statistical significance (Table 1), establishing the occurrence of a genetic interaction. Despite rescue of the hair cycle defect, only two $K 17^{-/-} \mathrm{TNF}^{-/-}$mice showed a normal hair coat (e.g., Fig. 6A; Table 1). Consistent with the latter, all $\mathrm{K}^{-7^{-/-}} \mathrm{TNF \alpha ^{-/- }}$ mice had fragile hair shafts (Table 1). Apoptosis and hair fragility thus represent independent phenomena in K17-null skin.

\section{Discussion}

The studies reported here identify two novel regulators of hair cycling, the cytoskeletal protein K17 and the cytokine TNF $\alpha$. Expression of K17 protein, or a functional equivalent (e.g., K16) (McGowan et al. 2002), is required

Table 1. Characterization of K17/TNF $\alpha$ double-knockout mice (P7 and P14)

\begin{tabular}{lcccrr}
\hline Genotype & Number of mice & Hair follicle apoptosis & Induction of FGF5 at P7 & Alopecia & Hair fragility \\
\hline Wild-type & 15 & $0 / 15$ & $0 / 15$ & $0 / 15$ & $0 / 15$ \\
K17 & 30 & $30 / 30$ & $15 / 15$ & $30 / 30$ & $30 / 30$ \\
$\mathrm{~K}^{-1} 7^{-/-} \mathrm{TNF}^{-/-}$ & 29 & $20 / 29^{\mathrm{a}}$ & $9 / 14^{\mathrm{b}}$ & $27 / 29$ & $29 / 29$ \\
\hline
\end{tabular}

${ }^{\text {a }} P<0.005$ according to Fisher's exact test.

${ }^{\mathrm{b}} P<0.01$ according to Fisher's exact test. 
Figure 6. Genetic interaction between $\mathrm{K} 17$ and TNF $\alpha$ pathway. $(A$, left $)$ Rescue of hair loss in ${\mathrm{K} 17^{-/-}}^{-} \mathrm{NNF} \alpha^{-/}$ mice. A $K 17^{-/-}$littermate is shown at right for reference. $\left(B, B^{\prime}\right)$ Hematoxylin/eosin-stained skin tissue sec-

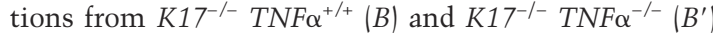
mice at P14. Arrows point to hair bulbs. Bars, $50 \mu \mathrm{m}$. $\left(C, C^{\prime}\right)$ TUNEL (green) and Hoechst (blue) dual stainings in backskin sections prepared from $\mathrm{K}^{-17^{-I-}} \mathrm{TNF \alpha}^{+/+}(\mathrm{C})$ and ${\mathrm{K} 17^{-/-}}^{\mathrm{TNF} \alpha^{-/-}}\left(\mathrm{C}^{\prime}\right)$ mice at P14. Arrows point to TUNEL positive staining. Bars, $50 \mu \mathrm{m} .\left(D, D^{\prime}\right)$ In situ hybridization for FGF5 mRNA in $\mathrm{K}^{-17^{-/-}} \mathrm{TNF}^{+/+}(D)$ and $\mathrm{K}_{17^{-/-}} \mathrm{TNF} \alpha^{-/-}\left(D^{\prime}\right)$ backskin at P7. Four percent paraformaldehyde-fixed frozen sections were hybridized with antisense $\left(D, D^{\prime}\right)$ or sense (not shown) probes. Bars, $50 \mu \mathrm{m}$. (Bulb) Hair bulb; (epi) epidermis; (mat) matrix; (ORS) outer root sheath. Asterisks denote melanin pigments in hair bulb.
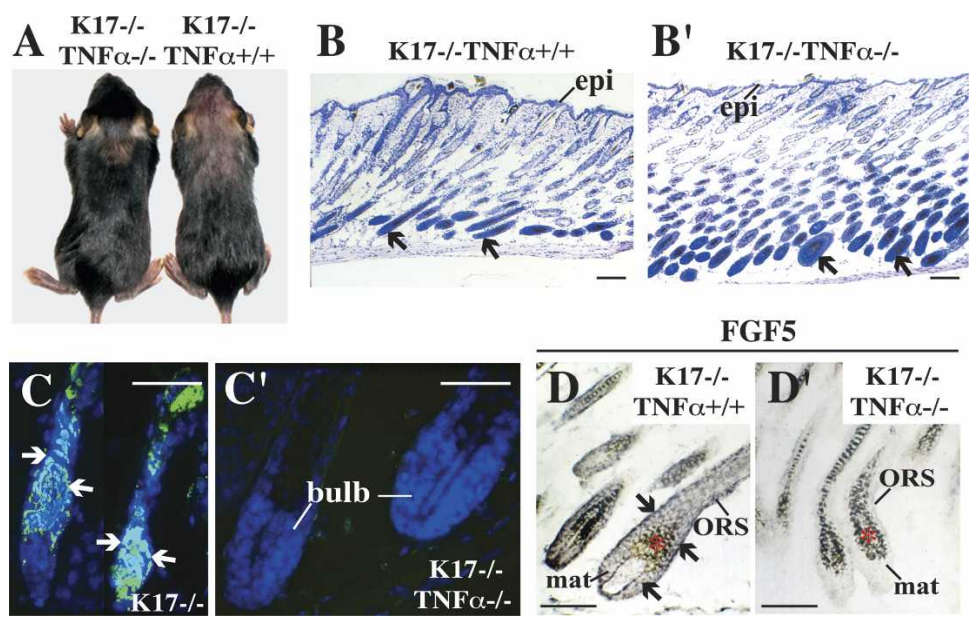

for the persistence of the anagen (growth) state in hair follicles. $T N F \alpha$, on the other hand, is required for the timely occurrence of the anagen-catagen transition. We provide genetic evidence that $K 17$ modulates the function of TNF $\alpha$ in the specific context of hair cycling, and biochemical evidence (albeit indirect) that TNF $\alpha$ signaling is enhanced in K17-null mouse skin tissue. That a keratin structural protein contributes to hair cycle regulation, and does so independently of its structural support role in epithelia, was unexpected and represents an exciting new direction for skin biology.

Unlike the case for keratins, a role in hair morphogenesis, and possibly in hair cycling as well, has already been defined for a TNF superfamily member, ectodysplasin (Eda), acting through its receptor Edar (Thesleff and Mikkola 2002). Although they affect hair growth in opposing ways, the catagen inducer TNF $\alpha$ (this study; see Ruckert et al. 2000) and anagen promoter ectodysplasin (Mustonen et al. 2003) share NF- $\mathrm{B}$ as a major intracellular target. In this study, NF- $\kappa \mathrm{B}$ was used as a readout for $\mathrm{TNF} \alpha / \mathrm{TNFR} 1$-dependent signaling at the anagencatagen transition in wild-type, K17-null, and TNF $\alpha$-null skin. The data derived from $T N F \alpha$-null skin at P14/P16, in particular, indicate that NF- $\mathrm{B}$ activity reliably reports on the loss of this cytokine. Our studies do not directly address the issue of NF-кB's role in this setting. Zhang et al. (2004) elegantly described how the RelA (p65) subunit of NF- $\mathrm{B}$ antagonizes a strong TNFR1-dependent proliferation signal during normal homeostasis in human epidermis reconstituted by grafting in mouse skin. These findings (see also Gugasyan et al. 2004) cemented the notion that NF-кB's antiproliferative influence in mature epidermis is unique compared with many other tissues (Bolotin and Fuchs 2003) including developing hair follicles (Schmidt-Ullrich et al. 2001). Given a reduced mitotic activity of hair matrix epithelial cells in K17-null skin at P5, activation of NF- $\mathrm{B}$ could act to slow down their proliferation at the end of anagen, as is the case in human epidermis (Zhang et al. 2004), while another signal would be required for commitment to apoptosis and catagen entry. While there is evidence that TNFR1-mediated apoptosis of epidermal keratinocytes in culture requires reduced NF-кB activity (see Qin et al. 2001; Basile et al. 2003; Konur et al. 2005), how the latter impacts the proliferation, differentiation, and/or apoptosis of this cell type is clearly a function of the global signaling environment (e.g., Poppelmann et al. 2005).

K17's ability to interact with TRADD provides an attractive, yet unproven mechanism to account for the genetic interaction between $K 17$ and TNFo in hair follicles. First, there is a precedent for modulation of $\mathrm{TNF} \alpha$ signaling in a keratin/TRADD-dependent fashion. Inada et al. (2001) showed a reverse correlation between the levels of K18, which binds TRADD directly, and susceptibility of epithelial cell lines to TNF $\alpha$-induced apoptosis. These authors proposed a cell-autonomous mechanism, keratin-dependent sequestration of TRADD, to account for this effect. Jaquemar et al. (2003) showed that loss of maternally derived TNF $\alpha$ significantly increases the viability of K8-null embryos (such embryos lack K8's partner protein $\mathrm{K} 18$ as well), although the mechanism involved may be distinct. Second, the conserved property of interacting with TRADD could account for the ability of K16 (and possibly K14) to prevent, in an age- and strain-specific fashion, the hair cycling defect in K17null hair follicles (McGowan et al. 2002). Third, TRADD participates to signal relay from receptors other than TNFR1, such that loss of the K17-TRADD interaction could also account for the fraction of the hair cycling defect that cannot be explained solely by TNF $\alpha$ signaling in K17-null mice (Table 1). As an example, IFN- $\gamma$ signals in a STAT $1 \alpha$ - and TRADD-dependent fashion (Wesemann et al. 2004) and is also required for the timely occurrence of the anagen-catagen transition in mouse hair follicles (Hirota et al. 2002, 2003). TNF $\alpha$, IFN- $\gamma$, and IL-1 $\beta$ cause significantly more apoptosis in mouse pelage hair follicles when administered intradermally together, rather than individually (Ruckert et al. 2000). In an apparent paradox, TRADD's adaptor function is essential to both the proapoptotic (DISC complex-dependent) and prosurvival (NF-kB-dependent) arms of TNF $\alpha$ signal relay (Micheau and Tschopp 2003), raising the concern that a simple TRADD sequestration model cannot mediate $\mathrm{K} 17$ 's influence on $\mathrm{TNF} \alpha$ signaling. This said, the 
level of intact c-FLIP protein is markedly reduced in K17null skin (in contrast to its mRNA), suggesting that the NF- $\kappa \mathrm{B}$-dependent arm of the $\mathrm{TNF} \alpha$ signal relay is subject to additional regulation. Clearly, development of suitable reagents and cellular models is needed to confirm the functional role of the keratin-TRADD interaction in TNF $\alpha$-treated keratinocytes, and explore alternative mechanisms.

A genetic approach can help toward further dissection of the hair cycling defect in K17-null mice. We have obtained evidence that one or more loci located proximal to the type I keratin gene cluster also modulate the impact of K17 loss. All the findings we report here involved progeny from the sixth and seventh backcrosses (N6, N7) of K17-null allele carriers into the $\mathrm{C} 57 \mathrm{Bl} / 6$ strain. The complete penetrance of the pelage hair phenotype observed under such conditions is eroded, however, with further backcrossing. When $\mathrm{N} 12 \mathrm{~K} 17^{+/-}$mice are interbred, only $\sim 25 \%$ of the $\mathrm{K} 17^{-/-}$progeny show a hair loss phenotype, implying a powerful modulatory role for modifier gene(s) located proximal to the K17 locus. The average amount of genomic DNA flanking an allele of interest changes from $\sim 30 \mathrm{cM}$ to $\sim 20 \mathrm{cM}$ from N6 to N12 (Peirce 2001; Olofsson and Holmdahl 2003). Intriguingly, there is a cluster of cytokine-encoding genes located 29-30 cM away from the K17 locus (11D; $1158.7 \mathrm{cM}$ ) on mouse chromosome 11 (Wilson et al. 1990; Wenderfer et al. 2000). These include genes for $I L-3, I L-4, I L-5, I L$ 13, interferon regulatory factor 1, granulocyte-macrophage colony-stimulating factor, and a few others. In light of the role of $T N F \alpha$ (this study) and IFN- $\gamma$ (Hirota et al. 2002, 2003) in regulating catagen entry in hair follicles, it makes sense that additional proinflammatory genes might impact the penetrance of the K17-null mutation. Identifying these genes, the cellular source of their protein products, and the mechanisms through which they act, should provide novel insight into hair cycling.

\section{Materials and methods}

\section{Animal models}

The K17-null mice (McGowan et al. 2002) used in this study were backcrossed into the $\mathrm{C} 57 \mathrm{Bl} / 6$ mouse strain for six or seven generations (N6, N7). TNF $\alpha$-null mice, backcrossed in the C57Bl/6 strain, were a gift from Dr. M. Meffert (Johns Hopkins University, Baltimore, MD). K17-TNF $\alpha$ double-null mice were created by mating the two single-knockout strains. Genotyping was done by PCR from mouse tail genomic DNA as described (McGowan et al. 2002). Genotyping at the TNF $\alpha$ locus was done by PCR, as follows: denaturation at $94^{\circ} \mathrm{C}$ for $1 \mathrm{~min}$; annealing at $62^{\circ} \mathrm{C}$ for $1 \mathrm{~min}$; elongation: $72^{\circ} \mathrm{C}$ for $1 \mathrm{~min}$, using the following primer pairs: null TNF $\alpha$ allele (forward, 5'-AGCCAACCAG GCAGGTTCTG-3'; and reverse, 5'-CCTTCTATCGCCTTCT TGACGAG- ${ }^{\prime}$ ) and wild-type allele (forward, 5'-AGCCAACC AGGCAGGTTCTG-3'; and reverse, 5' -TAGACAGAAGAGCG TGGTGG-3'). Mice were provided rodent chow and water ad libitum. All protocols were approved by the institutional Animal Care and Use Committee.

\section{Primary antibodies}

The following primary antibodies were used: rabbit polyclonal antisera against K17 (McGowan and Coulombe 1998), K16 (Bernot et al. 2002), K14 (Covance), c-FLIP (Upstate Biotechnology), TRADD (Santa Cruz Biotechnology), TRADD (provided by Dr. Masaki Inagaki, Aichi Cancer Research Institute, Nagoya, Japan) (Inada et al. 2001), IкB $\alpha$ (Santa Cruz Biotechnology), p65 (Santa Cruz Biotechnology), and lamin B (provided by Dr. Kathy Wilson, Johns Hopkins University, Baltimore, MD) (Zastrow et al. 2006), and mouse monoclonal antibodies to K10, BrdU, $\alpha$-tubulin, and actin (Sigma).

\section{Tissue harvesting, histological analyses, and BrdU labeling}

For studies of hair cycling, skin tissue was always obtained from the mid-back region of age- and gender-matched mouse littermates. For histology, tissues were fixed in Bouin's $\left(12 \mathrm{~h}, 4^{\circ} \mathrm{C}\right)$ prior to paraffin embedding. Five-micrometer sections were counterstained with hematoxylin and eosin. Alternatively, fresh-frozen tissues were embedded in OCT (Sakura Finetec) and $10-\mu \mathrm{m}$ sections were immunostained using the primary antibodies described above, followed by FITC- or Rhodamine-conjugated secondary antibodies (Kirkegaard and Perry Laboratories) (Bernot et al. 2004). TUNEL (Roche) and Hoechst (Sigma) stainings were performed on $4 \%$ paraformaldehyde-fixed, paraffin-embedded samples following the manufacturers' instructions (McGowan et al. 2002). For BrdU labeling, five P5 mice of each genotype were intraperitoneally injected with BrdU (20 $\mathrm{mg} / \mathrm{kg}$ body weight; Sigma) and sacrificed after $45 \mathrm{~min}$. Tenmicrometer-thick cryosections were fixed for $10 \mathrm{~min}$ in $10 \%$ formalin, PBS-washed, and stained with anti-BrdU (Sigma) as described (Paladini and Coulombe 1998). For each genotype, BrdU-labeled cells were counted in 50 hair bulbs (sectioned through dermal papillae) from 10 sections. The hair bulb area was measured with MacBAS version 2.5 software (Fuji Medical Systems USA). Data are presented as the average numbers of BrdU-positive cells per surface area of bulb tissue.

\section{In situ hybridization and Northern blot analysis}

Detailed protocols for in situ hybridization and Northern blot analyses were described (McGowan et al. 2002; Tong and Coulombe 2004). The probes used in this study included FGF5, FGFR2 (both provided by Dr. G. Martin, University of California at San Francisco, CA), $\beta$-tubulin, PTHRP (provided by Dr. C. Thompson, Johns Hopkins University, Baltimore, MD), c-FLIP and ICAM-1 (ordered from ATCC), ІкB $\alpha$ (provided by Dr. L. Lin, Johns Hopkins University, Baltimore, MD), TRADD (generated by RT-PCR; forward primer, 5'-CTGCGGTAGACAAGGTGA TCC-3'; reverse primer, 5'-CAGTACTAGACTTAGGCCAG GC-3'), TNFR1 (generated by RT-PCR; forward primer, 5'-GCC CCCACCTCTGTTCAGAAATG-3'; reverse primer, 5'-GTTG TGGGTGTGGCTTTATCGC-3'). Northern blots were imaged and quantitated using a Fujifilm BAS-2500 PhosphorImager. Values were normalized to signal for $\beta$-tubulin. Each Northern analysis was conducted at least two times, with similar findings.

\section{Keratinocyte cultures and their analysis}

Primary keratinocytes were collected from P2/P3 mouse littermates (wild type or K17 null), plated, and cultured as described (Bernot et al. 2004). Transient transfections were carried out using Lipofectamine 2000 (Invitrogen) using the manufacturer's instructions. After $48 \mathrm{~h}$, cultures were fixed with $4 \%$ paraformaldehyde, permeabilized with methanol, and processed for indirect immunofluorescence labeling (Bernot et al. 2004). Studies involving proapoptotic treatments were conducted at $48 \mathrm{~h}$ after 
plating. Cultures were treated for $24 \mathrm{~h}$ with DMSO vehicle control (CTL), $5 \mu \mathrm{g} / \mathrm{mL}$ CHX, as well as $50 \mu \mathrm{g} / \mathrm{mL}$ Jo2 (the agonistic antibody to FAS ligand) (Gilbert et al. 2001), $100 \mathrm{ng} / \mathrm{mL} \mathrm{TNF} \alpha$, $5 \mu \mathrm{g} / \mathrm{mL}$ TRAIL in the presence of $5 \mu \mathrm{g} / \mathrm{mL}$ CHX. TUNEL (Roche) and Hoechst (Sigma) stainings were performed on 4\% paraformaldehyde-fixed, $0.1 \%$ Triton X-100-permeablized cultured cells, to identify apoptotic cells. Alternatively, caspase activity (activated caspases 2, 3, 6, 7, 8, 9, and 10) was quantified by fluorimetry as follows: At $24 \mathrm{~h}$ after induction of apoptosis, caspase substrate (Roche) diluted in lysis buffer was added to each well and incubated for $2 \mathrm{~h}$ at $37^{\circ} \mathrm{C}$. Substrate cleavage was measured using a PerkinElmer HTS 7000 Plus spectrofluorometer, with excitation and emission wavelengths set at 485 and $535 \mathrm{~nm}$, respectively, as recommended (Roche). A calibration curve obtained using free Rhodamine-110 fluorochrome was used for calculating values for each sample. In separate studies, the frequency of apoptotic cells after TNF $\alpha$ treatment was determined in primary cultures of K17-null keratinocytes transfected with wild-type K17. Transient transfection was done at $12 \mathrm{~h}$ after plating using lipofectamine 2000 according to the manufacturer's instructions (Invitrogen). Proapoptotic treatment (100 ng/mL TNF $\alpha+5 \mu \mathrm{g} / \mathrm{mL} \mathrm{CHX)} \mathrm{was} \mathrm{performed} \mathrm{at} 48 \mathrm{~h}$ after plating. At $24 \mathrm{~h}$ later, cells were subjected to immunofluorescence labeling for $\mathrm{K} 17$ followed by TUNEL staining. In separate transfection studies, the GFP-TRADD fusion constructs were provided by Dr. Andrew Thorburn (Wake Forest University, Winston-Salem, NC) (Bender et al. 2005).

\section{Immunoprecipitation and Western blot analysis}

Wild-type skin keratinocytes in primary culture were solubilized with 2\% Empigen BB (Calbiochem) buffer. Protein A-Sepharose beads (Amersham Biosciences) were washed with PBS, conjugated to rabbit antibody against TRADD or normal rabbit serum, then added with an equal volume of cell lysate and incubated for $12 \mathrm{~h}$ at $4^{\circ} \mathrm{C}$ (Bernot et al. 2004). After three washes ( $2 \%$ Empigen BB buffer), bound protein was eluted with $5 \times$ gel sample buffer containing $\beta$-mercaptoethanol. Eluted proteins were subjected to SDS-PAGE and Western blot analysis. Western blot analysis of protein extracts from depilated skin or clipped hair was performed as described (McGowan et al. 2002; Bernot et al. 2004). For quantification, NIH image software was used as described (Paladini and Coulombe 1998).

\section{Cell fractionation}

Nuclear and cytoplasmic extracts were prepared according to Lammerding et al. (2004), with modifications. Skin samples were cut into small pieces and homogenized in ice-cold buffer A (0.1\% Triton X-100, 10 mM EDTA, 10 mM EGTA, 10 mM KCl, $10 \mathrm{mM}$ HEPES, $1 \mathrm{mM}$ DTT, $0.5 \mathrm{mM}$ PMSF, protease inhibitor cocktail) on ice for $1 \mathrm{~min}$. The homogenate was spun $(16,000 \mathrm{~g}$, $5 \mathrm{~min}, 4^{\circ} \mathrm{C}$ ). The supernatant was stored as the cytoplasmic fraction. Nuclei-containing pellets were washed in ice-cold PBS and incubated in ice-cold buffer B ( $1 \mathrm{mM}$ EDTA, 1 mM EGTA,

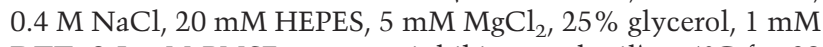
DTT, $0.5 \mathrm{mM}$ PMSF, protease inhibitor cocktail) at $4^{\circ} \mathrm{C}$ for 30 min with mixing. The nuclear extract was centrifuged $(16,000 g$, $10 \mathrm{~min}, 4^{\circ} \mathrm{C}$ ), and the supernatant was stored as the nuclear fraction. The nuclear and cytoplasmic fractions were subjected to SDS-PAGE and Western blot analysis. Fraction purity was verified by immunoblotting for tubulin (cytoplasmic) and lamin $\mathrm{B}$ (nuclear) antigens.

\section{Acknowledgments}

We thank Dr. Kelsie Bernot and Ms. Eunhye Park for their contribution; members of the Coulombe laboratory for support; Dr.
Mollie Meffert for providing TNF $\alpha$-null mice, reagents, and advice; Drs. Gail Martin, Masaki Inagaki, Li Lin, and Andrew Thorburn for providing reagents; and Drs. Joel Pomerantz, Michael Caterina, Roger Reeves, Susan Craig, Catherine Thompson, and Katherine Wilson for reagents and/or advice. This work was supported by NIAMS/NIH grant AR44232 to P.A.C.

\section{References}

Basile, J.R., Eichten, A., Zacny, V., and Munger, K. 2003. NF$\kappa \mathrm{B}$-mediated induction of $\mathrm{p} 21$ (Cip1/Waf1) by tumor necrosis factor $\alpha$ induces growth arrest and cytoprotection in normal human keratinocytes. Mol. Cancer Res. 1: 262-270.

Beaudoin III, G.M., Sisk, J.M., Coulombe, P.A., and Thompson, C.C. 2005. Hairless triggers reactivation of hair growth by promoting Wnt signaling. Proc. Natl. Acad. Sci. 102: 1465314658.

Bender, L.M., Morgan, M.J., Thomas, L.R., Liu, Z.G., and Thorburn, A. 2005. The adaptor protein TRADD activates distinct mechanisms of apoptosis from the nucleus and the cytoplasm. Cell Death Differ. 12: 473-481.

Bernot, K., McGowan, K., and Coulombe, P.A. 2002. Keratin 16 expression defines a subset of epithelial cells during skin morphogenesis and the hair cycle. J. Invest. Dermatol. 119: 1137-1149.

Bernot, K.M., Coulombe, P.A., and Wong, P. 2004. Skin: An ideal model system to study keratin genes and proteins. Methods Cell Biol. 78: 453-487.

Bolotin, D. and Fuchs, E. 2003. Cancer: More than skin deep. Nature 421: 594-595.

Caulin, C., Ware, C.F., Magin, T.M., and Oshima, R.G. 2000. Keratin-dependent, epithelial resistance to tumor necrosis factor-induced apoptosis. J. Cell Biol. 149: 17-22.

Cho, Y.M., Woodard, G.L., Dunbar, M., Gocken, T., Jimenez, J.A., and Foley, J. 2003. Hair-cycle-dependent expression of parathyroid hormone-related protein and its type I receptor: Evidence for regulation at the anagen to catagen transition. J. Invest. Dermatol. 120: 715-727.

Cotsarelis, G. and Millar, S.E. 2001. Towards a molecular understanding of hair loss and its treatment. Trends Mol. Med. 7: 293-301.

Coulombe, P.A. and Wong, P. 2004. Cytoplasmic intermediate filaments revealed as dynamic and multipurpose scaffolds. Nat. Cell Biol. 6: 699-706.

Foitzik, K., Lindner, G., Mueller-Roever, S., Maurer, M., Botchkareva, N., Botchkarev, V., Handjiski, B., Metz, M., Hibino, T., Soma, T., et al. 2000. Control of murine hair follicle regression (catagen) by TGF- $\beta 1$ in vivo. FASEB J. 14: 752760.

Fuchs, E. 1995. Keratins and the skin. Annu. Rev. Cell Dev. Biol. 11: 123-153.

Fuchs, E., Merrill, B.J., Jamora, C., and DasGupta, R. 2001. At the roots of a never-ending cycle. Dev. Cell 1: 13-25.

Gilbert, S., Loranger, A., Daigle, N., and Marceau, N. 2001. Simple epithelium keratins 8 and 18 provide resistance to Fas-mediated apoptosis. The protection occurs through a receptor-targeting modulation. J. Cell Biol. 154: 763-774.

Gilbert, S., Loranger, A., and Marceau, N. 2004. Keratins modulate c-Flip/extracellular signal-regulated kinase 1 and 2 antiapoptotic signaling in simple epithelial cells. Mol. Cell. Biol. 24: 7072-7081.

Gugasyan, R., Voss, A., Varigos, G., Thomas, T., Grumont, R.J., Kaur, P., Grigoriadis, G., and Gerondakis, S. 2004. The transcription factors c-rel and RelA control epidermal development and homeostasis in embryonic and adult skin via dis- 
tinct mechanisms. Mol. Cell. Biol. 24: 5733-5745.

Hadshiew, I.M., Foitzik, K., Arck, P.C., and Paus, R. 2004. Burden of hair loss: Stress and the underestimated psychosocial impact of telogen effluvium and androgenetic alopecia. $I$. Invest. Dermatol. 123: 455-457.

Hardy, M.H. 1992. The secret life of the hair follicle. Trends Genet. 8: 55-61.

Hebert, J.M., Rosenquist, T., Gotz, J., and Martin, G.R. 1994. FGF5 as a regulator of the hair growth cycle: Evidence from targeted and spontaneous mutations. Cell 78: 1017-1025.

Hirota, R., Tajima, S., Yoneda, Y., Tamayama, T., Watanabe, M., Ueda, K., Kubota, T., and Yoshida, R. 2002. Alopecia of IFN- $\gamma$ knockout mouse as a model for disturbance of the hair cycle: A unique arrest of the hair cycle at the anagen phase accompanied by mitosis. I. Interferon Cytokine Res. 22: 935-945.

Hirota, R., Tajima, S., Yoneda, Y., Okada, M., Tashiro, J., Ueda, K., Kubota, T., and Yoshida, R. 2003. Induction of hair regrowth in the alopecia site of IFN- $\gamma$ knockout mice by allografting and IFN- $\gamma$ injection into the transplantation site. $J$. Interferon Cytokine Res. 23: 433-439.

Hoffmann, A., Levchenko, A., Scott, M.L., and Baltimore, D. 2002. The IкB-NF-кB signaling module: Temporal control and gene activation. Science 298: 1241-1245.

Inada, H., Izawa, I., Nishizawa, M., Fujita, E., Kiyono, T., Takahashi, T., Momoi, T., and Inagaki, M. 2001. Keratin attenuates tumor necrosis factor-induced cytotoxicity through association with TRADD. J. Cell Biol. 155: 415-426.

Jamora, C., DasGupta, R., Kocieniewski, P., and Fuchs, E. 2003. Links between signal transduction, transcription and adhesion in epithelial bud development. Nature 422: 317-322.

Jaquemar, D., Kupriyanov, S., Wankell, M., Avis, J., Benirschke, K., Baribault, H., and Oshima, R.G. 2003. Keratin 8 protection of placental barrier function. J. Cell Biol. 161: 749-756.

Kondo, S. and Sauder, D.N. 1997. Tumor necrosis factor (TNF) receptor type 1 (p55) is a main mediator for TNF- $\alpha$-induced skin inflammation. Eur. J. Immunol. 27: 1713-1718.

Konur, A., Schulz, U., Eissner, G., Andreesen, R., and Holler, E. 2005. Interferon (IFN)- $\gamma$ is a main mediator of keratinocyte (HaCaT) apoptosis and contributes to autocrine IFN- $\gamma$ and tumour necrosis factor- $\alpha$ production. Br. J. Dermatol. 152: 1134-1142.

Kreuz, S., Siegmund, D., Scheurich, P., and Wajant, H. 2001. NF- $\kappa$ B inducers upregulate cFLIP, a cycloheximide-sensitive inhibitor of death receptor signaling. Mol. Cell. Biol. 21: 3964-3973.

Ku, N.O., Soetikno, R.M., and Omary, M.B. 2003. Keratin mutation in transgenic mice predisposes to Fas but not TNFinduced apoptosis and massive liver injury. Hepatology 37: 1006-1014.

Lammerding, J., Schulze, P.C., Takahashi, T., Kozlov, S., Sullivan, T., Kamm, R.D., Stewart, C.L., and Lee, R.T. 2004. Lamin A/C deficiency causes defective nuclear mechanics and mechanotransduction. J. Clin. Invest. 113: 370-378.

Langbein, L., Rogers, M.A., Praetzel, S., Winter, H., and Schweizer, J. 2003. K6irs1, K6irs2, K6irs3, and K6irs4 represent the inner-root-sheath-specific type II epithelial keratins of the human hair follicle. J. Invest. Dermatol. 120: 512-522.

Lavker, R.M., Miller, S., Wilson, C., Cotsarelis, G., Wei, Z.G., Yang, J.S., and Sun, T.T. 1993. Hair follicle stem cells: Their location, role in hair cycle, and involvement in skin tumor formation. J. Invest. Dermatol. 101 (1 Suppl): 16S-26S.

Lin, K.K., Chudova, D., Hatfield, G.W., Smyth, P., and Andersen, B. 2004. Identification of hair cycle-associated genes from time-course gene expression profile data by using replicate variance. Proc. Natl. Acad. Sci. 101: 15955-15960.
Marcelo, C.L., Kim, Y.G., Kaine, J.L., and Voorhees, J.J. 1978. Stratification, specialization, and proliferation of primary keratinocyte cultures. Evidence of a functioning in vitro epidermal cell system. J. Cell Biol. 79: 356-370.

McGowan, K.M. and Coulombe, P.A. 1998. Onset of keratin 17 expression coincides with the definition of major epithelial lineages during skin development. J. Cell Biol. 143: 469-486.

McGowan, K.M., Tong, X., Colucci-Guyon, E., Langa, F., Babinet, C., and Coulombe, P.A. 2002. Keratin 17 null mice exhibit age- and strain-dependent alopecia. Genes \& Dev. 16: 1412-1422.

Micheau, O. and Tschopp, J. 2003. Induction of TNF receptor I-mediated apoptosis via two sequential signaling complexes. Cell 114: 181-190.

Millar, S.E. 2002. Molecular mechanisms regulating hair follicle development. J. Invest. Dermatol. 118: 216-225.

Min, J.K., Kim, Y.M., Kim, S.W., Kwon, M.C., Kong, Y.Y., Hwang, I.K., Won, M.H., Rho, J., and Kwon, Y.G. 2005. TNFrelated activation-induced cytokine enhances leukocyte adhesiveness: Induction of ICAM-1 and VCAM-1 via TNF receptor-associated factor and protein kinase C-dependent NF$\kappa \mathrm{B}$ activation in endothelial cells. J. Immunol. 175: 531-540.

Moynagh, P.N. 2005. The NF-кB pathway. J. Cell Sci. 118: 45894592.

Muller-Rover, S., Handjiski, B., van der Veen, C., Eichmuller, S., Foitzik, K., McKay, I.A., Stenn, K.S., and Paus, R. 2001. A comprehensive guide for the accurate classification of murine hair follicles in distinct hair cycle stages. J. Invest. Dermatol. 117: 3-15.

Mustonen, T., Pispa, J., Mikkola, M.L., Pummila, M., Kangas, A.T., Pakkasjarvi, L., Jaatinen, R., and Thesleff, I. 2003. Stimulation of ectodermal organ development by Ectodysplasin-A1. Dev. Biol. 259: 123-136.

Olofsson, P. and Holmdahl, R. 2003. Positional cloning of Ncf1-A piece in the puzzle of arthritis genetics. Scand. $J$. Immunol. 58: 155-164.

Omary, M.B., Coulombe, P.A., and McLean, W.H.I. 2004. Intermediate filament proteins and their associated diseases. $N$. Engl. J. Med. 351: 2087-2100.

Oshima, R.G. 2002. Apoptosis and keratin intermediate filaments. Cell Death Differ. 9: 486-492.

Paladini, R.D. and Coulombe, P.A. 1998. Directed expression of keratin 16 to the progenitor basal cells of transgenic mouse skin delays skin maturation. J. Cell Biol. 142: 1035-1051.

Panteleyev, A.A., Paus, R., Wanner, R., Nurnberg, W., Eichmuller, S., Thiel, R., Zhang, J., Henz, B.M., and Rosenbach, T. 1997. Keratin 17 gene expression during the murine hair cycle. J. Invest. Dermatol. 108: 324-329.

Pasparakis, M., Alexopoulou, L., Episkopou, V., and Kollias, G. 1996. Immune and inflammatory responses in TNF $\alpha$-deficient mice: A critical requirement for TNF $\alpha$ in the formation of primary B cell follicles, follicular dendritic cell networks and germinal centers, and in the maturation of the humoral immune response. J. Exp. Med. 184: 1397-1411.

Paus, R. and Cotsarelis, G. 1999. The biology of hair follicles. N. Engl. J. Med. 341: 491-497.

Paus, R. and Foitzik, K. 2004. In search of the 'hair cycle clock': A guided tour. Differentiation 72: 489-511.

Peirce, J. 2001. Looking at old tools in new ways: Using knockouts as congenics to study QTLs. Genome Res. 11: 14691471.

Poppelmann, B., Klimmek, K., Strozyk, E., Voss, R., Schwarz, T., and Kulms, D. 2005. NFkB-dependent down-regulation of tumor necrosis factor receptor-associated proteins contributes to interleukin-1-mediated enhancement of ultraviolet B-induced apoptosis. J. Biol. Chem. 280: 15635-15643. 
Qin, J.Z., Bacon, P., Chaturvedi, V., and Nickoloff, B.J. 2001. Role of NF- $\mathrm{B}$ activity in apoptotic response of keratinocytes mediated by interferon- $\gamma$, tumor necrosis factor- $\alpha$, and tumor-necrosis-factor-related apoptosis-inducing ligand. J. Invest. Dermatol. 117: 898-907.

Ruckert, R., Lindner, G., Bulfone-Paus, S., and Paus, R. 2000. High-dose proinflammatory cytokines induce apoptosis of hair bulb keratinocytes in vivo. Br. J. Dermatol. 143: 10361039.

Schmidt-Ullrich, R., Aebischer, T., Hulsken, J., Birchmeier, W., Klemm, U., and Scheidereit, C. 2001. Requirement of NF$\kappa \mathrm{B} /$ Rel for the development of hair follicles and other epidermal appendices. Development 128: 3843-3853.

Scott, M.L., Fujita, T., Liou, H.C., Nolan, G.P., and Baltimore, D. 1993. The p65 subunit of NF-к B regulates Ік B by two distinct mechanisms. Genes \& Dev. 7: 1266-1276.

Thesleff, I. and Mikkola, M.L. 2002. Death receptor signaling giving life to ectodermal organs. Sci. STKE 2002: PE22.

Tong, X. and Coulombe, P.A. 2004. A novel mouse type I intermediate filament gene, keratin $17 \mathrm{n}(\mathrm{K} 17 \mathrm{n})$, exhibits preferred expression in nail tissue. I. Invest. Dermatol. 122: 965-970.

Wachter, T., Sprick, M., Hausmann, D., Kerstan, A., McPherson, K., Stassi, G., Brocker, E.B., Walczak, H., and Leverkus, M. 2004. cFLIPL inhibits tumor necrosis factor-related apoptosis-inducing ligand-mediated NF- $\mathrm{B}$ activation at the death-inducing signaling complex in human keratinocytes. J. Biol. Chem. 279: 52824-52834.

Wawersik, M. and Coulombe, P.A. 2000. Forced expression of keratin 16 alters the adhesion, differentiation, and migration of mouse skin keratinocytes. Mol. Biol. Cell 11: 33153327.

Wehrli, P., Viard, I., Bullani, R., Tschopp, J., and French, L.E. 2000. Death receptors in cutaneous biology and disease. $J$. Invest. Dermatol. 115: 141-148.

Weiss, R.A., Eichner, R., and Sun, T.T. 1984. Monoclonal antibody analysis of keratin expression in epidermal diseases: A 48- and 56-kdalton keratin as molecular markers for hyperproliferative keratinocytes. J. Cell Biol. 98: 1397-1406.

Wenderfer, S.E., Slack, J.P., McCluskey, T.S., and Monaco, J.J. 2000. Identification of 40 genes on a $1-\mathrm{Mb}$ contig around the IL-4 cytokine family gene cluster on mouse chromosome 11. Genomics 63: 354-373.

Wesemann, D.R., Qin, H., Kokorina, N., and Benveniste, E.N. 2004. TRADD interacts with STAT1- $\alpha$ and influences interferon- $\gamma$ signaling. Nat. Immunol. 5: 199-207.

Wilson, S.D., Billings, P.R., D'Eustachio, P., Fournier, R.E., Geissler, E., Lalley, P.A., Burd, P.R., Housman, D.E., Taylor, B.A., and Dorf, M.E. 1990. Clustering of cytokine genes on mouse chromosome 11. J. Exp. Med. 171: 1301-1314.

Yoneda, K., Furukawa, T., Zheng, Y.J., Momoi, T., Izawa, I., Inagaki, M., Manabe, M., and Inagaki, N. 2004. An autocrine/paracrine loop linking Keratin 14 aggregates to tumor necrosis factor $\alpha$-mediated cytotoxicity in a keratinocyte model of epidermolysis bullosa simplex. J. Biol. Chem. 279: 7296-7303.

Zastrow, M.S., Flaherty, D.B., Benian, G.M., and Wilson, K.L. 2006. Nuclear Titin interacts with A- and B-type lamins in vitro and in vivo. J. Cell Sci. 119: 239-249.

Zhang, J.Y., Green, C.L., Tao, S., and Khavari, P.A. 2004. NF-кB RelA opposes epidermal proliferation driven by TNFR1 and JNK. Genes \& Dev. 18: 17-22. 


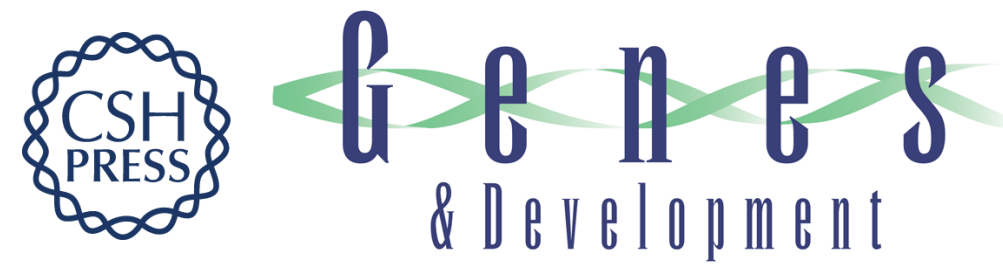

\section{Keratin 17 modulates hair follicle cycling in a TNF $\alpha$-dependent fashion}

Xuemei Tong and Pierre A. Coulombe

Genes Dev. 2006, 20:

Access the most recent version at doi:10.1101/gad.1387406

Supplemental

Material

References

This article cites 67 articles, 29 of which can be accessed free at:

http://genesdev.cshlp.org/content/20/10/1353.full.html\#ref-list-1

\section{License}

Email Alerting Service

http://genesdev.cshlp.org/content/suppl/2006/04/27/20.10.1353.DC1 right corner of the article or click here.

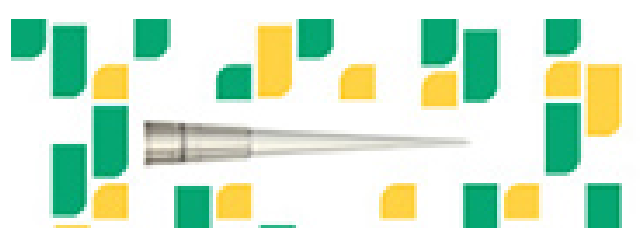

Focused on your science. 